\title{
Digitalization of Industry and Education
}

\author{
Mariya Ostapenko ${ }^{1, *}$ and Vladlena Nazarova ${ }^{1}$ \\ ${ }^{1}$ Industrial University of Tyumen, Tyumen, Russia
}

\begin{abstract}
The fourth industrial revolution, associated with the introduction of robotics, cyber-physical systems, artificial intelligence, neural networks, affects all spheres of human life. There is a need for specialists with the appropriate skills. The article discusses the elements of Industry 4.0: Internet of Things, robotization, PLM system. The impact of digitalization on the educational sector is also considered.
\end{abstract}

The fourth industrial revolution, or Industry 4.0, is a new stage in the development of mankind, where digital transformation of production is taking place. It is characterized by transition to cyber-physical systems, where the boundaries between the physical, biological and digital spheres are blurred.

Industry 4.0 involves introduction of cyber-physical systems into factory processes, that is, digitalization of the enterprise. The digitalization of industrial enterprises is necessary to solve the problems connected with processing of large amounts of data in large-scale industries.

The Internet of Things, or IoT, Industrial IoT, with its many components of the IoT stack, from IoT platforms to industrial IoT gateways, devices, and more, plays a key role in Industry 4.0. The goal of the enterprise IoT is to create value for business organizations and customers through IoT services. [1].

The digitalization of an enterprise also implies introduction of robots into production process (i.e., robotization of production). There are 2.7 million industrial robots in factories around the world, according to the World Robotics Report 2020 Industrial Robot. According to the President of the International Federation of Robotics, today the number of industrial robots operating in factories around the world is the highest in history.

The International Federation of Robotics presented 5 main trends in the development of robots for 2021:

1) Robots learn new tricks;

2) Robots work in smart factories;

3) Robots enter new markets;

4) Robots reduce carbon footprint;

5) Robots help protect supply chains.

For the development of both mechanical engineering and industry as a whole, the key condition is the growth of intelligent production systems and digitalization of support for the entire product life cycle.

\footnotetext{
*Corresponding author: ms_ostapenko@mail.ru
} 
The PLM system is used in enterprises as a tool for product lifecycle management, that is, from the start-up process to service support. The essence of PLM technology is to create, fill in and change the structure of information data that determine the state of the product throughout its entire life cycle, from development to disposal. The PLM system connects the means and methods of information support for products at all these stages. Figure 1 shows the used automated control systems at the stages of the product life cycle.

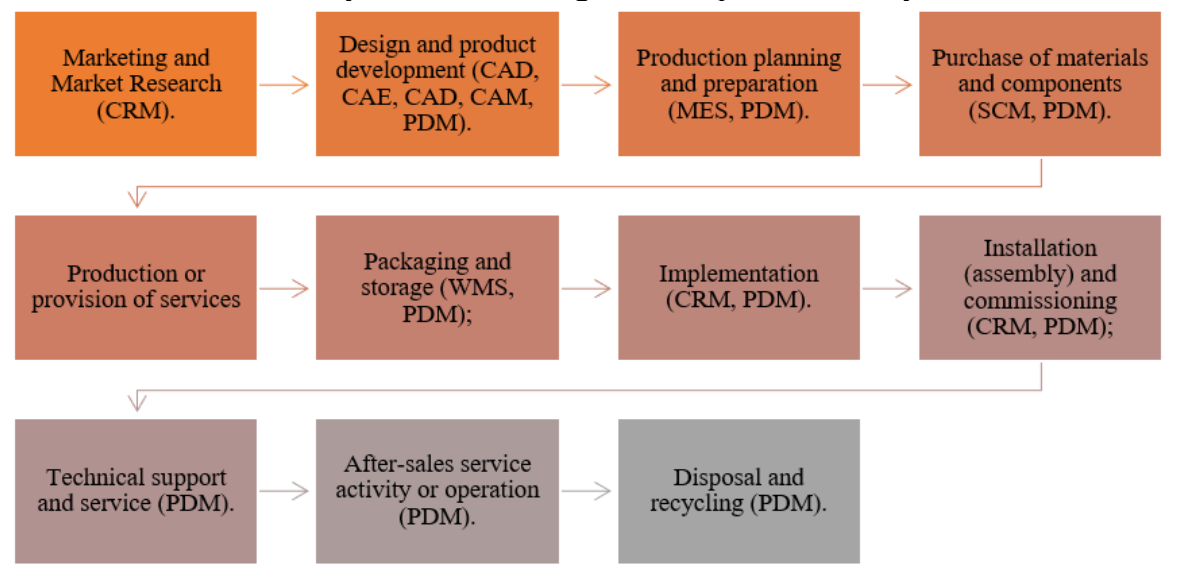

Fig. 1. The use of automated control systems at product life cycle stages

Software development company Siemens PLM Software is a leader in the PLM technology market. Many companies implement this software to reduce costs.

Table 1 shows enterprises both in Russia and foreign countries, which have implemented PLM technologies.

Table 1. Formatting sections, subsections and subsubsections.

\begin{tabular}{|l|l|l|l|}
\hline No. & The name of the enterprise & Software & Implementation results \\
\hline \multicolumn{3}{|c|}{ Russia } \\
\hline 1 & $\begin{array}{l}\text { KONAR CJSC (manufacturer } \\
\text { of oil and gas equipment) }\end{array}$ & Solid Edge & $\begin{array}{l}\text { Reducing design time for complex products } \\
\text { by switching to 3D modeling }\end{array}$ \\
\hline 3 & $\begin{array}{l}\text { DOMODEDOVO Airport } \\
\text { complex }\end{array}$ & $\begin{array}{l}\text { Tecnomatix } \\
\text { Plant } \\
\text { Simulation }\end{array}$ & $\begin{array}{l}\text { Modernization of Domodedovo airport in } \\
\text { order to increase passenger traffic }\end{array}$ \\
\hline 4 & $\begin{array}{l}\text { NPO ISKRA JSC (production } \\
\text { of rocket engines) }\end{array}$ & $\begin{array}{l}\text { Solid Edge, } \\
\text { Teamcenter }\end{array}$ & $\begin{array}{l}\text { Simplification of the design process } \\
\text { through the use of CAD functionality } \\
\text { Solid Edge Truss \& Piping Creation }\end{array}$ \\
\hline 1 & $\begin{array}{l}\text { ATK company (aerospace } \\
\text { and industry } \\
\text { production) }\end{array}$ & $\begin{array}{l}\text { Teamcenter, } \\
\text { NX }\end{array}$ & $\begin{array}{l}\text { Implementation of projects according to } \\
\text { plan within budget, ensuring high } \\
\text { technological level of solutions thanks to } \\
\text { PLM implementation }\end{array}$ \\
\hline 2 & $\begin{array}{l}\text { Shenzhen Hangsheng } \\
\text { Electronics Co. Ltd } \\
\text { (production of automobile } \\
\text { electrical equipment) }\end{array}$ & $\begin{array}{l}\text { NX, Teamcenter } \\
\text { Eollner Elektronik AG } \\
\text { (electronics manufacturing) }\end{array}$ & $\begin{array}{l}\text { Implementing Teamcenter system to } \\
\text { provide comprehensive product data } \\
\text { management }\end{array}$ \\
\hline 3 & $\begin{array}{l}\text { S K O D A A U T O } \\
\text { Tecnomatix }\end{array}$ & $\begin{array}{l}\text { Significantly shorter cycle times, streamline } \\
\text { production processes and lower costs }\end{array}$ \\
\hline 5 & $\begin{array}{l}\text { S I e m e n S } \\
\text { Tecnomatix }\end{array}$ & $\begin{array}{l}\text { Expansion of product line and acceleration } \\
\text { of production and logistics processes }\end{array}$ \\
\hline
\end{tabular}


The demand for the latest technology, as well as the day-to-day technological advancements, make the career of an engineer an exciting one. Technological innovation affects work, skill development and career choices. In the context of internationalization, informatization and marketization, the talents of engineering science and technology cultivated in universities hardly meet the needs of reforming society and industry, as well as the needs of transforming the regime of national economic development and creating an innovative country [2]. In the future, engineers will need much more skills and abilities to design fundamentally new technical solutions, which means that the demand for different types of engineers will increase. The type of engineers required will depend on the specific sector. For example, civil engineers will be in need to modernize the urban environment we live in, mechanical engineers - to improve the means of transportation for our travels, biomedical and chemical engineers - to help overcome difficult health problems, and computer engineers - to develop technologies that will help implement all the changes.

Due to the rapidly changing technologies, employers constantly update requests for new specialists. Based on these requirements, educational institutions are revising their curricula and introducing new areas of training, taking into account specialties that will be in demand on the labor market in the near future. Many of the professions of the future are specialties that emerged at the junction of two already existing areas. Let's see what areas of training will complement or will be the impetus for the creation of new curricula in universities in the near future.

It is clear that there is a trend towards the development of information technology and automation of production processes, and this will continue for the foreseeable future. In this respect, universities need to keep pace with technological progress and take into account the emerging requirements when developing curricula for preparation of competent and indemand specialists. There is no doubt that in the future specialists with knowledge of IT technologies will be in demand.

Chernyshov E.A. notes that the lack of qualified personnel today is one of the main obstacles in the development of priority sectors [3]. Therefore, the factor supporting the growth of labor productivity is the increased requirements for the level of professional training of engineers and technical personnel.

Also, as noted by MA Eremeev, one of the factors contributing to the growth of labor productivity is a decrease in the use of manual or low-skilled labor [4].

The changing labor and technological needs of the global economy are reshaping the nature of engineering training, requiring a much broader range of competencies than just mastering science and technology disciplines. In their paper, Marcela Hernandez-deMenendez \& Ruben Morales-Menendez note that the growing awareness of the importance of technological innovation for economic competitiveness and national security requires a new priority for applied fundamental engineering research [5].

The university today is focused on the production of specialists who will contribute to economic development in the future. High-tech enterprises all over the world experience a shortage of qualified personnel. And with the development and implementation of digital technologies, employers constantly update requests for new personnel. Getting a highly qualified specialist is a problem for an enterprise, getting a good job is a problem for a specialist [6].

The close interaction and interpenetration of fundamental and applied research, the interand multidisciplinary nature of new science-intensive technologies that allow solving complex problems in traditional and related fields require updating the paradigms of engineering activity and, as a result, engineering education.

The main contradiction of higher engineering education is a discrepancy between professional competencies acquired by graduates of technical universities in the process of 
their education, and the increased requirements of high-tech enterprises, design and scientific organizations.

The main function of an engineering profession is the ability to manipulate material, energy and information resources, thereby creating a benefit for humanity. Engineering education, like other professional education, is responsible for training engineers who can remove existing persistent obstacles and prevent future problems from arising. It follows from the above that the education of engineers at a university should keep pace with actively developing technologies. Universities today are the basis for innovation, development of science and supply of new scientific information for the development of technology and social environment. Examples of this are such well-known universities as MIT, Oxford, Harvard, Cambridge, etc.

Engineering principles learned at different levels are supported by hands-on exercises supported by hands-on labs. This is done in fully equipped laboratories for analog and digital electronics, communications technology, power systems, robotics, PLC, pneumatics and automation, mechanical equipment, mechanical workshop, materials and testing laboratories. Research laboratories, including engineering ones, have been set up at the leading universities in the world on basis of universities. They conduct research that integrates engineering theories and experiments. Table 2 lists the universities and their laboratories.

Table 2. Research laboratories in universities.

\begin{tabular}{|c|c|c|}
\hline No & University & Laboratories \\
\hline 1 & University of Michigan & $\begin{array}{l}\text { 1. 3D Lab } \\
\text { 2. Ford Battery Lab } \\
\text { 3. Functional and In-Vivo MRI Labs }\end{array}$ \\
\hline 2 & Imperial College London & $\begin{array}{l}\text { 1. Environmental Laboratory } \\
\text { 2. Hydrodynamics Laboratory } \\
\text { 3. Infrastructure Materials }\end{array}$ \\
\hline 3 & $\begin{array}{l}\text { University of Bristol Beacon House } \\
\text { Queens Road }\end{array}$ & $\begin{array}{l}\text { 1. Metallurgy laboratory } \\
\text { 2. Relative motion robotics rig } \\
\text { 3. Bristol Robotics Laboratory (BRL) }\end{array}$ \\
\hline 4 & CARLETON UNIVERSITY & $\begin{array}{l}\text { 1. HIH Saravanamuttoo Gas Turbine Laboratory } \\
\text { 2. The Advanced Real-Time Simulation Laboratory } \\
\text { 3. The Advanced Real-Time Simulation Laboratory }\end{array}$ \\
\hline 5 & National University of Singapore & $\begin{array}{l}\text { 1. The Control and Mechatronics } \\
\text { 2. Materials } \\
\text { 3. The Experimental Mechanics Laboratory }\end{array}$ \\
\hline
\end{tabular}

In the laboratories presented, research is carried out by students. They are engineered with the latest equipment and instruments to promote excellence in teaching, research and consulting services. Working in the laboratory is the first hands-on experience an engineering student has in his or her career. The number of successful practical applications performed by students in engineering laboratories helps them to become more confident in their knowledge and skills, laboratories play a crucial role in the all-round development of engineering students as well as teachers. Laboratories will always be a key part of the engineering education ecosystem for years to come.

In their article 'Ranking assessment of the competitiveness of agricultural universities' Y. Klochkov, E. Akri, V. Samorukov and K. Evdokimov [7] say that for stable growth and increasing the competitiveness of a university it is necessary to build sustainable development systems, such as in PR-management, as well as in educational and scientific fields. In this regard, the following conclusions can be drawn: 1) it is necessary to determine indicators for the teaching staff and researchers that will help build the necessary system for promoting the university. 2) build the corporate culture of the university so that the quality of teaching and the quality of research is a priority. 
Also, the problem lies in the lack of higher education programs that train specialists that meet the needs of a modern enterprise. Therefore, it is necessary to revise and update the training programs for specialists. For 2021, seven major engineering professions and indemand technical skills according to Talent 101 - Mobile Application Developer, Database Administrator, DevOps Engineer, Network Architect, Information Security Analyst, AI/ML Engineer, Data Specialist. One can take courses in these specialties. Obtaining higher education in these specialties is currently impossible, due to the lack of training programs.

Some companies are looking for such skills to develop their IoT platforms. Companies such as Siemens, GE and Dassault Systemes are promoting digital tools that help plan assembly lines ahead of time and predict errors that may arise during production. The world of engineering is becoming more and more integrated into the computer world. As a result, engineers are expected to have a better understanding of computer science and how to incorporate these technological advances into their workflow and projects.

Of course, the main goal of engineering is still to change nature ethically and economically for the benefit of humanity, but engineers are increasingly doing this from a computer terminal rather than from the floor of a workshop or a field truck. However, most educational engineers agree that students need to have some contact, or at least make them believe they have had contact with nature. Continuous discussion and further research are needed to determine the most effective, efficient way to achieve this.

\section{References}

1. I. Lee, The Internet of Things for enterprises: An ecosystem, architecture, and IoT service business model, Internet of Things, v.7, pp. 100078(2019).

2. M. Li, Discussion on University Teaching Reform under the Education Massification, EURASIA J Math Sci Tech Ed. Modestum Publishing LTD, v. 13, № 12, pp. 8359-8365 (2017).

3. E.A. Chernyshov, A.A. Evlampiev and A.D. Romanov, Improvement of Quality of Training of Students of Engineering Specialties with Use of New Technologies, Atlantis Press, pp. 212-214 (2019).

4. M.A. Eremeev, I.M. Kublin, Formation of principles for ensuring efficiency of the system of remuneration and labor incentives, Modern economy: problems and solutions, 2011. v. 1, pp. 83-92 (2011).

5. M. Hernandez-de-Menendez, R. Morales-Menendez, Technological innovations and practices in engineering education: a review, Int J Interact Des Manuf, v. 13, № 2, pp. 713-728 (2019).

6. A.V. Dolzhenkova, Yu.S. Klochkov, Analysis of forecasting methods of demand for highly qualified specialists in the labor market, Federal State Autonomous Educational Institution of Higher Education Peter the Great St. Petersburg Polytechnic University, pp. 113-116 (2017).

7. Y. Klochkov et al, Ranking assessment of the competitiveness of agricultural universities, IOP Conf. Ser.: Mater. Sci. Eng. IOP Publishing, v. 666, pp. 012073 (2019). 